\title{
Serum Omentin Levels in Adolescent Girls With Anorexia Nervosa and Obesity
}

\author{
J. OŚWIĘCIMSKA ${ }^{1}$, A. SUWAŁA ${ }^{2}$, E. ŚWIĘTOCHOWSKA ${ }^{3}$, Z. OSTROWSKA $^{3}$, \\ P. GORCZYCA ${ }^{4}$, K. ZIORA-JAKUTOWICZ ${ }^{5}$, E. MACHURA ${ }^{1}$, M. SZCZEPAŃSKA ${ }^{1}$, \\ M. KUKLA ${ }^{6}$, M. STOJEWSKA ${ }^{1}$, D. ZIORA ${ }^{7}$, K. ZIORA $^{1}$
}

${ }^{1}$ Chair and Department of Pediatrics, SMDZ in Zabrze, Medical University of Silesia in Katowice, Zabrze, Poland, ${ }^{2}$ Anmedis, Warszawa, Poland, ${ }^{3}$ Department of Medical and Molecular Biology, SMDZ in Zabrze, Medical University of Silesia in Katowice, Zabrze, Poland, ${ }^{4}$ Chair and Department of Psychiatry, SMDZ in Zabrze, Medical University of Silesia in Katowice, Tarnowskie Góry, Poland, ${ }^{5}$ Department of Genetics, Institute of Psychiatry and Neurology, Warszawa, Poland, ${ }^{6}$ Department of Gastrology and Hepatology, SMK in Katowice, Medical University of Silesia in Katowice, Katowice, Poland, ${ }^{7}$ Chair and Department of Pneumonology and Tuberculosis, SMDZ in Zabrze, Medical University of Silesia in Katowice, Zabrze, Poland

Received June 8, 2014

Accepted December 5, 2014

On-line March 24, 2015

\section{Summary}

It is believed that omentin is secreted by stromal cells of adipose tissue and modulates insulin sensitivity. Data from a few studies have shown lower serum omentin in obese children and higher in anorexia nervosa. However, to date, there is lack of research on serum omentin concentrations in adolescent patients in a wide range of body mass index (BMI) and insulin resistance. In this cross-sectional study omentin-1 serum concentrations were evaluated using commercially available ELISA kit in 47 Polish girls with restrictive anorexia nervosa (AN), 50 with simple obesity (OB) and 39 healthy controls (C). The mean serum omentin-1 concentration in girls with AN was statistically significantly higher than that of $C$ and $O B$ girls. Statistically significant $(P<0.0001)$ negative correlations between the serum concentrations of omentin- 1 and body weight $(r=-0.73)$, BMI $(r=-0.75)$, standard deviation score for body mass index (BMI-SDS) $(r=-0.75)$, insulin $(r=-0.81)$ and HOMA-IR index $(r=-0.82)$ were seen in the entire examined population. We conclude, that omentin- 1 is the nutritional marker reflecting body weight and insulin resistance. Our findings support the hypothesized role of omentin in maintenance of body weight and regulation of appetite and suggest the adaptation of its secretion to body weight and glucose metabolism.

\section{Key words}

Omentin • Anorexia nervosa • Obesity • Eating disorders • Adolescent girls • Insulin

\section{Corresponding author}

J. Oświęcimska, Department of Pediatrics, Medical University of Silesia in Katowice, ul. 3-Maja 13/15, 41-800 Zabrze, Poland. Fax: +48 32 2718701. E-mail: smina@poczta.onet.pl

\section{Introduction}

Anorexia nervosa (AN) and obesity (OB) are disorders at the extreme ends of the nutritional spectrum, and are characterized by marked reductions versus increases in body fat content, changes in energy stores as well as various hormonal axes.

The adipose tissue is the source of a large number of signaling molecules with numerous functions known as adipocytokines. They are involved in the regulation of metabolism, inflammatory processes, and body mass. Serum adipocytokine concentrations in AN and obesity can represent a sensitive parameter of nutritional status and fat tissue function (Leoni et al. 2010, Ondrak and Hackney 2010). 
Obesity is considered not only the condition of excess fat tissue, but is also associated with the development of a low-grade inflammation state that has deleterious effects on insulin action in adipocytes and disturbs their metabolic and hormonal function (Neels and Olefsky 2006).

On the other hand, AN constitutes an example of a chronic deficit of adipose tissue and is a good biological model of the chronic atrophy of adipose tissue, energy balance disorders, and nutrition disorders in humans (Nogal and Lewiński 2008).

In our previous studies we have demonstrated that serum leptin, resistin, visfatin, apelin and chemerin concentrations are decreased in $\mathrm{AN}$ and increased in obesity (Ziora et al. 2003, 2010a,b, 2011, 2012, Oświęcimska et al. 2014). These adipocytokines are positively related to stored fat, its distribution, insulin resistance, metabolic disorders and inflammation (McGown et al. 2014).

On the contrary, serum levels of a "beneficial" adiponectin, which is a one of a few insulin-sensitizing factors produced by adipose tissue that controls body weight, prevents atherosclerosis and negatively regulates immune function, are high or normal in AN and low in obesity (Ziora et al. 2010c, Terra et al. 2013).

Another insulin-sensitizing and antiinflammatory adiponectin is omentin, previously known as intelectin-1 secreted by stromal cells of the visceral adipose tissue (VAT), where its expression is 20 times higher than in the subcutaneous adipose tissue (SAT) (Yang et al. 2006, Wurm et al. 2007, Fain et al. 2008, Olszanecka-Glinianowicz et al. 2009, Yamawaki 2011, Ohashi et al. 2014).

There are two isoforms of omentin: omentin-1 and omentin-2 known. Omentin-1 is detected in the circulation and occurs in higher concentrations in VAT than omentin-2, which is released mainly to the intestinal lumen and is not detected in plasma (de Souza Batista et al. 2007).

The biological functions of omentin are not fully known, however there are some reports about its role in energy homeostasis. It is suggested that it increases insulin sensitivity, increases the transport of glucose stimulated by insulin in isolated human adipocytes and regulating the fat distribution (Yang et al. 2006, de Souza Batista et al. 2007).

Recent findings by Brunetti et al. (2011, 2013) suggest that omentin may also be involved in regulation of appetite.
So far omentin has been studied primarily in the context of insulin sensitivity, but its role in the pathophysiology of weight disorders is still poorly understood.

It has been reported that in the obese adults (de Souza Batista et al. 2007, Tan et al. 2008, Pan et al. 2010, El-Mesallamy et al. 2011, Auguet et al. 2011, Moreno-Navarrete et al. 2011) and children (Catli et al. 2014) serum omentin-1 concentrations are low and they increase concomitantly with the body weight loss (Moreno-Navarrete et al. 2010). The literature on the behavior and role of omentin in humans with body weight deficit caused by AN is limited to only one study (Guo et al. 2013).

Therefore, the objective of this study was to evaluate the serum omentin concentrations in girls with AN and compare these levels with the results obtained from healthy and obese girls.

\section{Subjects and Methods}

The examined group consisted of 47 girls who, following pediatric examination, psychological evaluation, and psychiatric consultation were diagnosed with the restrictive form of $\mathrm{AN}$ according to the Diagnostic and Statistical Manual of Mental Disorders, 4th edition (DSM-IV) classification (mean age, 15.4 \pm 1.6 years). These criteria for AN included intense fear of gaining weight, a refusal to maintain body weight $>85 \%$ of the expected weight for a given age and height, and three consecutive missed periods and either refusal to admit the seriousness of the weight loss, undue influence of shape or weight on one's self image, or a disturbed experience in one's shape or weight (American Psychiatric Association 2004).

Participants in the AN group were examined during the first 2 days of hospitalization before therapy was started. Eligibility criteria consisted of a stable general medical condition and the absence of clinical signs of dehydration. The initial results of additional laboratory investigations (serum electrolytes, aspartate and alanine aminotransferases, and creatinine) excluded those with hepatic and renal pathologies. Participants with any organic or psychiatric disorders other than eating disorders that could cause cachexia were excluded. None of the participants took any medications, including hormone drugs within the past 3 months or had infections within the last month before the study. All participants were non-smokers and had secondary amenorrhea. 
The control group (C) included 39 healthy regularly menstruating female volunteers with the standard deviation score for body mass index (BMI-SDS) between -2.0 and +2.0 who were recruited from secondary schools (mean age, $16.0 \pm 2.2$ years).

We also examined a group of 50 girls with simple obesity (OB) defined as BMI-SDS $>2.0$ (mean age, $15.1 \pm 1.9$ years) with normal glucose tolerance.

Participants from OB group were examined in the obesity outpatient clinic at their first presentation there. Eligibility criteria consisted of a simple obesity (i.e. resulting from excessive calorie intake), regular menses, stable medical condition and normal glucose tolerance in oral glucose tolerance test. The initial results of additional laboratory investigations (aspartate and alanine aminotransferases, creatinine, total cholesterol,
HDL- and LDL-cholesterol, triglycerides, TSH) excluded those with hepatic, renal and thyroid pathologies. Participants with any organic or psychiatric disorders were excluded. None of the participants took any medications, including hormone drugs, used slimming diets, applied increased physical effort within the past 3 months or had infections within the last month before the study. All participants were non-smokers.

All examined girls were at the pubertal stage of Tanner IV-V. In all participants, body mass index (BMI) [body weight $(\mathrm{kg}) /$ height $\left(\mathrm{m}^{2}\right)$ ] and BMI-SDS were calculated according to current Polish population normal ranges (Palczewska and Niedźwiedzka 2002).

Clinical characteristics of the study participants are shown in Table 1.

Table 1. Clinical characteristics of the examined groups of girls.

\begin{tabular}{llll}
\hline & $\mathbf{C}(\mathbf{n}=\mathbf{3 9})$ & $\mathbf{A N}(\mathbf{n}=\mathbf{4 7})$ & OB $(\mathbf{n}=\mathbf{5 0})$ \\
\hline Age (years) & $16.0 \pm 2.2(11.5 ; 16.0)$ & $15.4 \pm 1.6(11.5 ; 17.7)$ & $15.05 \pm 1.9(11.2 ; 17.9)$ \\
Body weight $(\mathrm{kg})$ & $55.4 \pm 7.5(40.6 ; 75.0) *$ & $38.7 \pm 5.3(28.0 ; 48.0) *$ & $91.8 \pm 16.8(54.2 ; 133.8) *^{\#}$ \\
Height $(\mathrm{cm})$ & $164.2 \pm 1.20(148.9 ; 179.0)$ & $162.6 \pm 6.7(143.5 ; 176.5)$ & $165.5 \pm 7.8(152.2 ; 182.0)$ \\
BMI $\left(\mathrm{kg} / \mathrm{m}^{2}\right)$ & $20.5 \pm 2.1(16.7 ; 24.6)$ & $14.6 \pm 1.5(11.4 ; 17.3) *$ & $33.5 \pm 5.2(23.5 ; 52.0) *^{*}$ \\
BMI-SDS & $0.2 \pm 1.0(-1.7 ; 1.99)$ & $-3.0 \pm 0.8(-5.3 ;-1.9) *$ & $7.6 \pm 2.9(2.9 ; 17.8) *^{* \#}$ \\
Insulin $(\mathrm{mIU} / \mathrm{l})$ & $4.20 \pm 0.49(3.2 ; 5.2)$ & $2.32 \pm 0.33(1.8 ; 3.1) *$ & $13.92 \pm 2.98(10.1 ; 23.0) *^{*}$ \\
Fasting glucose & $4.6 \pm 0.1(4.3 ; 5.2)$ & $4.3 \pm 0.1(3.1 ; 5.2)$ & $4.7 \pm 0.2(4.1 ; 5.5)$ \#\# $^{*}$ \\
(mmol/l) & $0.86 \pm 0.1(0.66 ; 1.06)$ & $0.45 \pm 0.07(0.35 ; 0.60) *$ & $2.93 \pm 0.66(1.84 ; 5.28) *^{*}$ \\
HOMA-IR & & & \\
\hline
\end{tabular}

Data are mean \pm SD (range). AN, anorexia nervosa group; OB, obesity group; C, healthy controls group; SD, standard deviation; BMI, body mass index; BMI-SDS, BMI standard deviation score for age and sex, according to the normal ranges for Polish children. ${ }^{*} P<0.0001, \mathrm{AN}$ vs. C; OB vs. C; ${ }^{\#} P<0.0001 \mathrm{OB}$ vs. AN; ${ }^{\# \#} \mathrm{P}<0.0005 \mathrm{OB}$ vs. $\mathrm{C}$

This study was approved by the Bioethics Committee at the Medical University of Silesia in Katowice (No. L. dz. KNW/0022/KB1/2/I/11), and written informed consent was obtained from all examined participants and their parents or legal guardians before their participation in this study.

\section{Laboratory assays}

To determine serum hormone concentrations, blood was drawn between 7:00 AM and 8:30 AM after at least a 12-h fast, in follicular phase in menstruating girls. Serum was frozen at $-70{ }^{\circ} \mathrm{C}$ until the time of assay. Serum omentin-1 concentrations were determined using the immunoenzymatic method with the application of the
Human Omentin ELISA kit (BioVendor, Brno, Czech Republic) according to the manufacturer's protocol. Concentrations were determined on the basis of the standard curve made for a series of dilutions of the standards available in the kit (recombinant human omentin). The absorbance of the samples was determined by Universal Microplate Spectrophotometer ( $\mu Q U A N T$, Biotek Inc. Winooski, VT, United States) using the wavelength of $450 \mathrm{~nm}$. The sensitivity of the kit was $0.5 \mathrm{ng} / \mathrm{ml}$. The intra- and inter-assay coefficients of variations were $3.6 \%$ and $4.6 \%$, respectively. The determination of insulin concentration was performed by IRMA (immunoradiometric assay kit; Immunotech, Praha, Czech Republic). 
Serum fasting glucose was evaluated on Cobas 6000 analyzer with c501 module (Roche Diagnostics, Basel, Switzerland). HOMA-IR (homeostasis assessment model-insulin resistance) index was calculated using the formula HOMA-IR = (fasting insulin [mIU/l] $\mathrm{x}$ fasting glucose) $[\mathrm{mmol} / 1] / 22.5$.

\section{Statistical analysis}

MedCalc software v. 12.4.0.0 (Ostend, Belgium) was used for statistical calculations. Results are presented as means \pm standard deviation (SD). The level of statistical significance was set at $\mathrm{P}=0.05$. The normality of the data was verified by Shapiro-Wilk test, and the homogeneity of variance was confirmed by Levene test. Log transformation (natural logarithm, ln) was performed on HOMA-IR index and insulin data, as they did not fit a Gaussian distribution in order to use parametric tests. ANOVA followed by post-hoc HSD Tukey test or the Kruskal-Wallis test (if distribution of data was different from normal) was used for intergroup comparisons. Correlations were analyzed by Spearman's test. Multiple linear regression analysis was performed in forward stepwise selection to identify independent relationships and to adjust for covariate effects.

\section{Results}

The mean age of girls in the AN group was similar to that of girls in the other groups $(\mathrm{C}, \mathrm{OB})$. The mean body weight, BMI and BMI-SDS of girls with AN were statistically significantly lower $(P<0.0001)$ compared with those in the healthy controls or obese girls. In the obese group these values were significantly higher than in the healthy participants $(P<0.0001)$ (Table 1$)$.

The mean serum concentration of insulin in the AN group as well as HOMA-IR index were significantly $(P<0.0001)$ lower $(2.32 \pm 0.33 \mathrm{mIU} / 1$ and $0.45 \pm 0.07$, respectively) compared with the $\mathrm{C}(4.20 \pm 0.49 \mathrm{mIU} / 1$ and $0.86 \pm 0.1$, respectively) and the OB groups (13.92 \pm $2.98 \mathrm{mIU} / 1$ and $2.93 \pm 0.66$, respectively). Serum insulin concentrations and HOMA-IR index in the OB group were significantly higher $(P<0.0001)$ than those in the $\mathrm{C}$ and AN patients (Table 1).

The mean serum omentin concentration in girls with AN $(46.1 \pm 3.8 \mathrm{ng} / \mathrm{ml})$ was statistically significantly higher $(P<0.0001)$ than that of healthy $(34.3 \pm 2.6 \mathrm{ng} / \mathrm{ml})$ and obese girls $(30.7 \pm 2.5 \mathrm{ng} / \mathrm{ml})$. Serum omentin in the OB group was significantly lower than in $\mathrm{C}$ participants $(P<0.0001)$ (Fig. 1). After controlling for BMI-SDS and HOMA-IR these differences remained significant $(P<0.0001)$.

Statistically significant $(\mathrm{P}<0.0001)$ negative correlations between the serum concentrations of omentin-1 and body weight $(\mathrm{r}=-0.73)$, BMI $(\mathrm{r}=-0.75)$, BMI-SDS ( $\mathrm{r}=-0.75)$ (Fig. 2), insulin $(\mathrm{r}=-0.81)$ and HOMA-IR index ( $r=-0.82$ ) (Fig. 3) were seen in the entire examined population. After adjustment for BMI-SDS and age partial correlations between omentin-1, ln insulin and ln HOMA-IR were weaker $(\mathrm{r}=-0.26$ and $\mathrm{r}=-0.30$ respectively), but remained significant $(\mathrm{P}<0.005)$.

HOMA-IR index remained independent predictor of serum omentin-1 concentrations in a model including age, BMI-SDS, fasting glucose and insulin ( $\beta=-0.83 ; \mathrm{P}<0.0001$; adjusted $\mathrm{R}^{2}=0.68$ ).

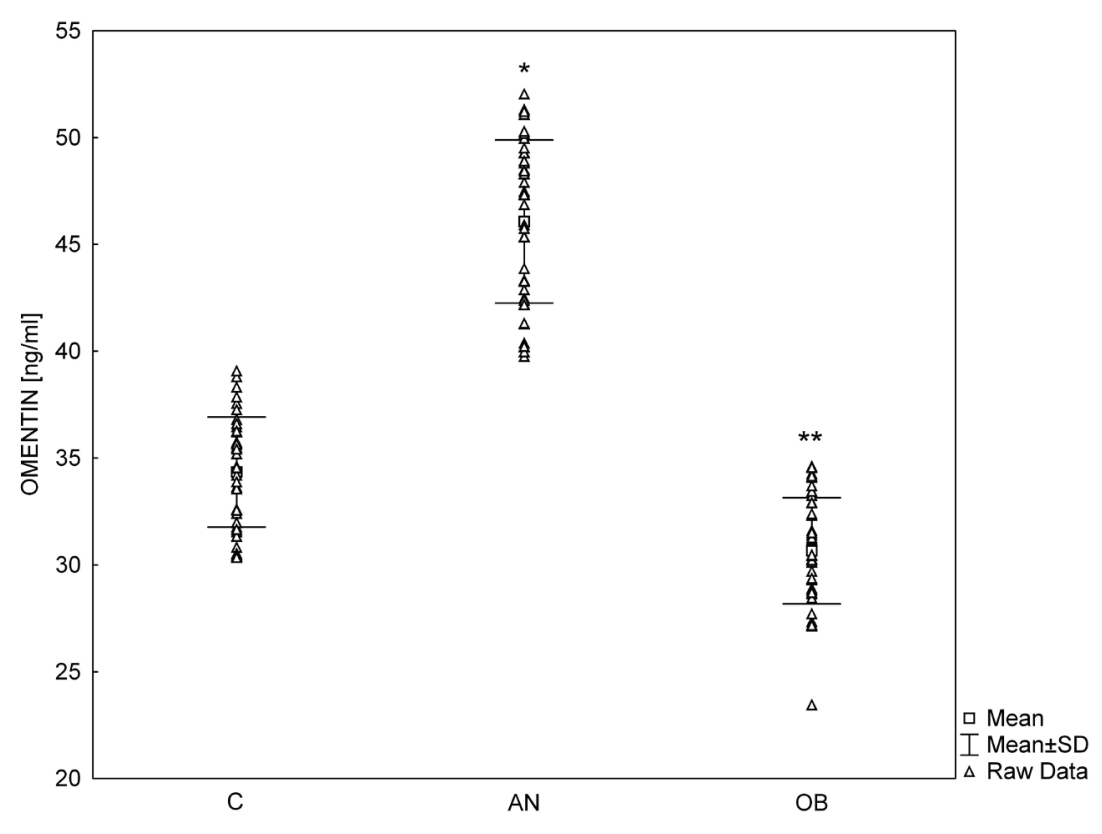

Fig. 1. Mean omentin serum concentrations $(\mathrm{ng} / \mathrm{ml})$ in the examined groups. AN, anorexia nervosa group; $\mathrm{OB}$, obesity group; $\mathrm{C}$, healthy controls group. $* P<0.0001$ vs. C group, $* * P<0.0001$ vs. AN group 

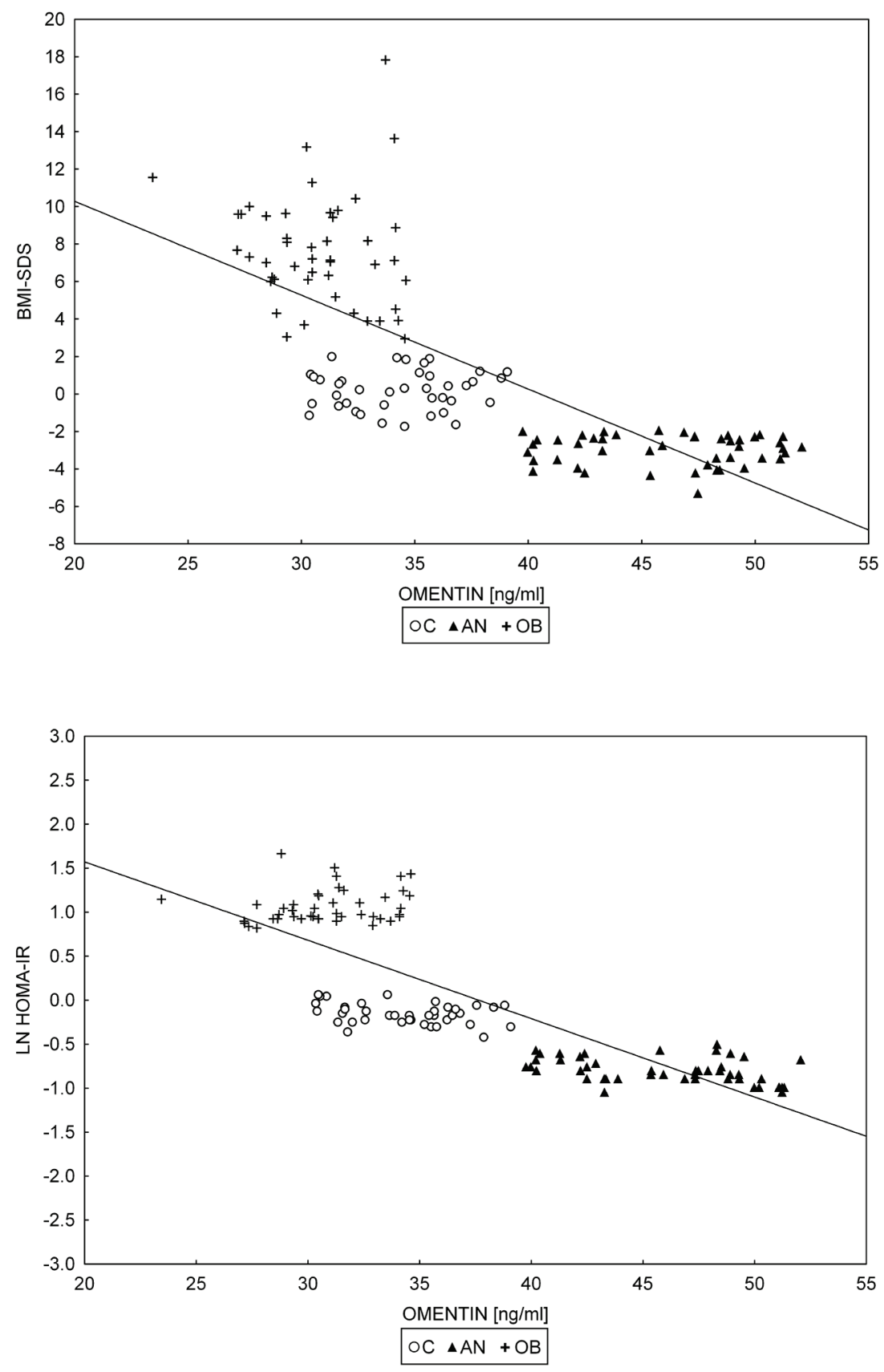

Fig. 2. Correlation between BMI $\left(\mathrm{kg} / \mathrm{m}^{2}\right)$ and serum omentin concentrations $(\mathrm{ng} / \mathrm{ml})$ in all examined girls $(r=-0.75 ; \quad P<0.0001) . \quad A N$, anorexia nervosa group; $\mathrm{OB}$, obesity group; $\mathrm{C}$, healthy controls group

Fig. 3. Correlation between HOMA-IR index and serum omentin concentrations $(\mathrm{ng} / \mathrm{ml})$ in all examined girls $(r=-0.82 ; \quad P<0.0001) . \quad A N$, anorexia nervosa group; $\mathrm{OB}$, obesity group; $C$, healthy controls group

\section{Discussion}

Omentin is a novel adipokine that is shown to be decreased in obesity and negatively associated with BMI, insulin resistance and metabolic syndrome in adults (de Souza Batista et al. 2007, Tan et al. 2008, Pan et al. 2010, El-Mesallamy et al. 2011).

Considering the growing epidemics of eating disorders and obesity in adolescents it is essential to establish how serum adipocytokines differ in accordance with weight status and insulin sensitivity in this population. It should be emphasized, that the advantage of research on adipocytokines in children is the lack of be overt metabolic comorbidities and/or concomitant medication as the progression of obesity and related disease is early in this group. None of our participants had abnormal fasting glucose levels or impaired glucose tolerance either hyperlipidemia. Therefore we can recognize our obesity group as "metabolically healthy".

We, for the first time investigated the concentrations of omentin-1 in adolescent girls with wide variety of BMI and HOMA-IR. Our results demonstrated that serum omentin-1 concentrations are significantly higher in AN and significantly lower in obesity comparing with healthy subjects of normal weight. We also showed that although omentin-1 is closely negatively 
associated with BMI and HOMA-IR index in a group of adolescent girls with a wide range of BMI and HOMA-IR, the above mentioned differences are still present after adjustment for BMI and HOMA-IR.

Although BMI is somewhat controversial index of fat mass, it is simple and widely used in clinical practice. For adolescents, BMI seems to be a good criterion for obesity classification and is generally associated to the onset and development of risk factors that can predispose to a higher incidence of metabolic and functional disorders, in addition to being easy to use and correlating to body fat (Rodríguez et al. 2004).

Data according serum omentin-1 concentrations in children are scarce and contradictory. Our findings are in line with the results obtained by Catli et al. (2013) in obese and normal weight children and Guo et al. (2013) in case of adolescent girls with AN.

On the other hand, Prats-Puig et al. (2011) demonstrated that in prepubertal young children (aged 5-9 years) with a normal distribution of weight and height increased serum omentin-1 levels are associated with poorer metabolic profile and familial prevalence of diabetes, but not with body weight or fat. These authors speculate that in younger children elevated serum omentin-1 may result from compensatory mechanism whereby this insulin-sensiting adipocytokine attenuates metabolic abnormalities (Prats-Puig et al. 2011). This was indirectly confirmed by Catli et al. (2013), since their pubertal children had higher BMI and HOMA-IR values than prepubertal ones suggesting the development of obesity and its metabolic consequences with age. Puberty did not influenced serum omentin-1 levels in this study (Catli et al. 2013).

It cannot be, however excluded that above mentioned discrepancies result from different affinities of the antibodies used for omentin-1 assay to the various molecular forms of this adipocytokine and/or its related protein - intelectin-2, which shares $60 \%$ amino acid identity (Prats-Puig et al. 2011).

The regulation of omentin-1 secretion in adipose tissue is poorly understood. According to the research by Tan et al. (2008) insulin and glucose decrease the production and expression of omentin mRNA in VAT, and hyperinsulinemia significantly reduces the omentin-1 serum concentration in healthy individuals. These findings suggest that glucose and insulin directly or indirectly regulate the synthesis of omentin. Omentin, in turn, may modulate the metabolism of glucose and insulin sensitivity (Yamawaki 2011).
The association between obesity and insulin resistance is widely known (Invitti et al. 2003, KasaVubu et al. 2005), whereas on the opposite end of the nutritional spectrum in the acute stage of $\mathrm{AN}$ serum insulin levels and HOMA index are low, protecting these subjects against hypoglycemia (Prioletta et al. 2011, Dostálova et al. 2009).

In our study serum omentin-1 concentrations correlated negatively with BMI, serum insulin and insulin resistance. However, only HOMA-IR was the only independent negative predictor of serum omentin-1 concentrations in a model including age, BMI-SDS, fasting glucose and insulin.

Our findings are consistent with previous results obtained in pediatric and adult patients where the negative correlations between serum omentin-1 levels and HOMA-IR or serum insulin have been reported (de Souza Batista et al. 2007, Tan et al. 2008, MorenoNavarrete et al. 2010, Pan et al. 2010, El-Mesallamy et al. 2011, Auguet et al. 2011, Catli et al. 2014). Some authors demonstrated also negative relationship between serum omentin-1 and BMI (de Souza Batista et al. 2007, Moreno-Navarrete et al. 2010, Pan et al. 2010, El-Mesallamy et al. 2011), but the others (Auguet et al. 2011, Prats-Puig et al. 2011) not, probably due to the fact that BMI is not an ideal predictor of insulin resistance.

High serum omentin-1 levels in anorexia nervosa may result also from dieting and excessive physical effort.

Dieting may influence serum omentin-1 levels in result of both reduction of body weight and improved insulin sensitivity. In obese women and men subjected to a 4-month low-calorie diet, a significant increase in serum omentin-1 concentration was observed. Apart from reduced BMI, an increased concentration of omentin-1 was accompanied by improvement in insulin sensitivity as evaluated by HOMA-IR index and the fasting insulin level. Similar to our study, the level of serum omentin-1 correlated negatively with BMI, body weight, and insulin levels (Moreno-Navarrete et al. 2010).

The influence of aerobic physical exercises on the omentin concentration has been also demonstrated (Saremi et al. 2010). It should be noted here, that most of the patients with AN obtained a low body weight not only due to nutrition restrictions but also due to an intensive physical effort which may contribute to high omentin-1 levels in these patients.

Another potential factor affecting omentin concentration in anorexia nervosa is low estradiol 
concentration. Higher serum omentin concentrations were reported in women than in men (Moreno-Navarrete et al. 2010) and in the study by Tan et al. (2008) the expression of mRNA for omentin-1 in adipose tissue and its serum concentration correlated negatively with $17 \beta$-estradiol. It should be noted that all our patients with AN had amenorrhea and hypogonadotropic hypogonadism.

The results of our study confirm the previous observations that serum omentin-1 levels are predominantly dependent on obesity and insulin resistance. However, even after adjustment for BMI and HOMA-IR index we observed significantly different serum omentin-1 concentrations between the groups.

Therefore, we can speculate if changes of serum omentin concentrations in our patients may result from compensatory mechanisms influencing the appetite as there is no sufficient research on this issue. However, in rats, chronic but not acute administration of omentin diminishes the expression of cocaine and amphetamineregulated transcript (CART) and $\mathrm{CRH}$ genes and increases norepinephrine synthesis and release in the hypothalamus. These findings suggest central orexigenic function of peripheral omentin (Brunetti et al. 2013).

We identified at least two potential limitations to this study. The first is its cross-sectional design. The second limitation is that body composition was not analyzed. The most common, popular, non-invasive and costless method of body composition assessment is bioimpedance (BIA). However, there is some evidence, that BIA has little utility in these patients, therefore we intentionally did not performed these measurements in this study (Piccoli et al. 2005, Haas et al. 2012).

We conclude, that omentin-1 is the nutritional marker reflecting body weight and insulin resistance. Our findings support the hypothesized role of omentin in maintenance of body weight and regulation of appetite and suggest the adaptation of its secretion to body weight and glucose metabolism.

\section{Conflict of Interest}

There is no conflict of interest.

\section{Acknowledgements}

The authors wish to thank Ms. Bożena Kostka for her excellent technical assistance. The project was financially supported by the Medical University of Silesia in Katowice, Poland, grant no KNW-1-074/P/2/0.

\section{References}

AMERICAN PSYCHIATRIC ASSOCIATION: Diagnostic and Statistical Manual of Mental Disorders, 4th ed. APA, Washington, DC, 2004.

AUGUET T, QUINTERO Y, RIESCO D, MORANCHO B, TERRA X, CRESCENTI A, BROCH M, AGUILAR C, OLONA M, PORRAS JA, HERNANDEZ M, SABENCH F, DEL CASTILlO D, RICHART C: New adipokines vaspin and omentin. Circulating levels and gene expression in adipose tissue from morbidly obese women. BMC Med Genet 12: 60, 2011.

BRUNETTI L, Di NISIO C, RECINELLA L, CHIAVAROLI A, LEONE S, FERRANTE C, ORLANDO G, VACCA M: Effects of vaspin, chemerin and omentin-1 on feeding behavior and hypothalamic peptide gene expression in the rat. Peptides 32: 1866-1871, 2011.

BRUNETTI L, ORLANDO G, FERRANTE C, RECINELLA L, LEONE S, CHIAVAROLI A, Di NISIO C, SHOHREH R, MANIPPA F, RICCIUTI A, VACCA M: Orexigenic effects of omentin-1 related to decreased $\mathrm{CART}$ and $\mathrm{CRH}$ gene expression and increased norepinephrine synthesis and release in the hypothalamus. Peptides 44: 66-74, 2013.

CATLI G, ANIK A, ABACU A, KUME T, BOBER E: Low omentin-1 levels are related with clinical and metabolic parameters in obese children. Exp Clin Endocrinol Diabetes 121: 595-600, 2013.

DE SOUZA BATISTA CM, YANG RZ, LEE MJ, GLYNN NM, YU DZ, PRAY J, NDUBUIZU K, PATIL S, SCHWARTZ A, KLIGMAN M, FRIED SK, GONG DW, SHULDINER AR, POLLIN TI, MCLENITHAN JC: Omentin plasma levels and gene expression are decreased in obesity. Diabetes 56: 1655-1661, 2007.

DOSTÁlOVÁ I, SEDLÁCKOVÁ D, PAPEZOVÁ H, NEDVÍDKOVÁ J, HALUZÍK M: Serum visfatin levels in patients with anorexia nervosa and bulimia nervosa. Physiol Res 58: 903-907, 2009. 
EL-MESALLAMY HO, EL-DERANY MO, HAMDY NM: Serum omentin-1 and chemerin levels are interrelated in patients with Type 2 diabetes mellitus with or without ischaemic heart disease. Diabet Med 28: 1194-1200, 2011.

FAIN JN, SACKS HS, BUEHRER B, BAHOUTH SW, GARRETT E, WOLF RY, CARTER RA, TICHANSKY DS, MADAN AK: Identification of omentin mRNA in human epicardial adipose tissue: comparison to omentin in subcutaneous, internal mammary artery periadventitial and visceral abdominal depots. Int J Obes (Lond) 32: 810-815, 2008.

GUO LJ, JIANG TJ, LIAO L, LIU H, HE HB: Relationship between serum omentin-1 level and bone mineral density in girls with anorexia nervosa. J Endocrinol Invest 36: 190-194, 2013.

HAAS V, RIEDL A, HOFMANN T, NISCHAN A, BURGHARDT R, BOSCHMANN M, KLAPP B: Bioimpedance and bioimpedance vector analysis in patients with anorexia nervosa. Eur Eat Disord Rev 20: 400-405, 2012.

INVITTI C, GUZZALONI G, GILARDINI L, MORABITO F, VIBERTI G: Prevalence and concomitants of glucose intolerance in European obese children and adolescents. Diabetes Care 26: 118-124, 2003.

KASA-VUBU JZ, LEE CC, ROSENTHAL A, SINGER K, HALTER JB: Cardiovascular fitness and exercise as determinants of insulin resistance in postpubertal adolescent females. J Clin Endocrinol Metab 90: 849-854, 2005.

LEONI MC, PIZZO D, MARCHI A: Adipocytokines: potential biomarkers for childhood obesity and anorexia nervosa. Minerva Pediatr 62: 171-178, 2010.

MCGOWN C, BIRERDINC A, YOUNOSSI ZM: Adipose tissue as an endocrine organ. Clin Liver Dis 18: 41-58, 2014.

MORENO-NAVARRETE JM, CATALÁN V, ORTEGA F, GÓMEZ-AMBROSI J, RICART W, FRÜHBECK G, FERNÁNDEZ-REAL JM: Circulating omentin concentration increases after weight loss. Nutr Metab (Lond) 7 : $27,2010$.

MORENO-NAVARRETE JM, ORTEGA F, CASTRO A, SABATER M, RICART W, FERNÁNDEZ-REAL JM: Circulating omentin as a novel biomarker of endothelial dysfunction. Obesity (Silver Spring) 19: 1552-1559, 2011.

NEELS JG, OLEFSKY JM: Inflamed fat: What starts the fire? J Clin Invest 116: 33-35, 2006.

NOGAL P, LEWIŃSKI A: Anorexia nervosa. (in Polish) Endokrynol Pol 59: 148-155, 2008.

OHASHI K, SHIBATA R, MUROHARA T, OUCHI N: Role of anti-inflammatory adipokines in obesity-related diseases. Trends Endocrinol Metab 25: 348-355, 2014.

OLSZANECKA-GLINIANOWICZ M, KOCEŁAK P, ORLIK B, HANDZLIK G, JUSZCZYK Ł: New adipokines good or bad for pathogenesis of insulin resistance? (in Polish) Endokrynol Otyłość 5: 236-244, 2009.

ONDRAK KS, HACKNEY AC: Body composition differences in normal weight, obese-overweight and anorexic adolescents: role of adipocytokines. Med Sport Sci 55: 32-42, 2010.

OŚWIĘCIMSKA J, ZIORA K, SUWAŁA A, ŚWIĘTOCHOWSKA E, GORCZYCA P, ZIORA-JAKUTOWICZ K, MACHURA E, SZCZEPAŃSKA M, OSTROWSKA Z, ZIORA D, SZALECKI M, STOJEWSKA M, MATUSIK P, MAŁECKA-TENDERA E: Chemerin serum levels in girls with anorexia nervosa. Neuro Endocrinol Lett 35: 490-496, 2014.

PALCZEWSKA I, NIEDŹWIECKA Z: Somatic development indices in children and youth of Warsaw. (in Polish) Med Wieku Rozwoj 2 (Suppl 1): 18-118, 2002.

PAN HY, GUO L, LI Q: Changes of serum omentin-1 levels in normal subjects and in patients with impaired glucose regulation and with newly diagnosed and untreated type 2 diabetes. Diabetes Res Clin Pract 88: 29-33, 2010.

PICCOLI A, CODOGNOTTO M, Di PASCOLI L, BOFFO G, CAREGARO L: Body mass index and agreement between bioimpedance and anthropometry estimates of body compartments in anorexia nervosa. JPEN J Parenter Enteral Nutr 29: 148-156, 2005.

PRATS-PUIG A, BASSOLS J, BARGALLÓ E, MAS-PARAREDA M, RIBOT R, SORIANO-RODRÍGUEZ P, BERENGÜÍ À, DÍAZ M, DE ZEGHER F, IBÁNEZ L, LÓPEZ-BERMEJO A: Toward an early marker of metabolic dysfunction: omentin-1 in prepubertal children. Obesity (Silver Spring) 19: 1905-1907, 2011.

PRIOLETTA A, MUSCOGIURI G, SORICE GP, LASSANDRO AP, MEZZA T, POLICOLA C, SALOMONE E, CIPOLLA C, DELLA CASA S, PONTECORVI A, GIACCARI A: In anorexia nervosa, even a small increase of abdominal fat is responsible for the appearance of insulin resistance. Clin Endocrinol (Oxf) 75: 202-206, 2011. 
RODRÍGUEZ G, MORENO LA, BLAY MG, BLAY VA, GARAGORRI JM, SARRÍA A, BUENO M: Body composition in adolescents: measurements and metabolic aspects. Int J Obes Relat Metab Disord 28 (Suppl 3): S54-S58, 2004.

SAREMI A, ASGHARI M, GHORBANI A: Effects of aerobic training on serum omentin-1 and cardiometabolic risk factors in overweight and obese men. J Sports Sci 28: 993-998, 2010.

TAN BK, ADYA R, FARHATULLAH S, LEWANDOWSKI KC, O'HARE P, LEHNERT H, RANDEVA HS: Omentin-1, a novel adipokine, is decreased in overweight insulin-resistant women with polycystic ovary syndrome: ex vivo and in vivo regulation of omentin-1 by insulin and glucose. Diabetes 57: 801-808, 2008.

TERRA X, AUGUET T, AGÜERA Z, QUESADA IM, ORELLANA-GAVALDÀ JM, AGUILAR C, JIMÉNEZMURCIA S, BERLANGA A, GUIU-JURADO E, MENCHÓN JM, FERNÁNDEZ-ARANDA F, RICHART C: Adipocytokine levels in women with anorexia nervosa. Relationship with weight restoration and disease duration. Int J Eat Disord 46: 855-861, 2013.

WURM S, NEUMEIER M, WEIGERT J, SCHÄFFLER A, BUECHLER C: Plasma levels of leptin, omentin, collagenous repeat-containing sequence of $26-\mathrm{kDa}$ protein (CORS-26) and adiponectin before and after oral glucose uptake in slim adults. Cardiovasc Diabetol 6: 7, 2007.

YAMAWAKI H: Vascular effects of novel adipocytokines: focus on vascular contractility and inflammatory responses. Biol Pharm Bull 34: 307-310, 2011.

YANG RZ, LEE MJ, HU H, PRAY J, WU HB, HANSEN BC, SHULDINER AR, FRIED SK, MCLENITHAN JC, GONG DW: Identification of omentin as a novel depot-specific adipokine in human adipose tissue: possible role in modulating insulin action. Am J Physiol Endocrinol Metab 290: E1253-E1261, 2006.

ZIORA K, GEISLER G, DYDUCH A, OSTROWSKA Z, SCHNEIBERG B, OŚWIĘCIMSKA J: Serum leptin levels in girls with anorexia nervosa. (in Polish) Endokrynol Pediatr 2: 33-40, 2003.

ZIORA K, OŚWIĘCIMSKA J, ŚWIĘTOCHOWSKA E, STOJEWSKA M, OSTROWSKA Z, SUWAŁA A, PAŁASZ W, PASIERB M, PIKIEWICZ-KOCH A, DYDUCH A: Serum fat tissue hormone - leptin concentrations in girls with anorexia nervosa. (in Polish) Endokrynol Pediatr 9: 43-53, 2010a.

ZIORA K, OŚWIĘCIMSKA J, ŚWIĘTOCHOWSKA E, ZIORA D, OSTROWSKA Z, STOJEWSKA M, KLIMACKA-NAWROT E, DYDUCH A, BŁOŃSKA-FAJFROWSKA B: Assessment of serum apelin levels in girls with anorexia nervosa. J Clin Endocrinol Metab 95: 2935-2941, 2010 b.

ZIORA K, OŚWIĘCIMSKA J, ŚWIĘTOCHOWSKA E, STOJEWSKA M, OSTROWSKA Z, SUWAŁA A, PAŁASZ W, PASIERB M, PIKIEWICZ-KOCH A, DYDUCH A: Serum fat tissue hormone - adiponectin concentrations in girls with anoresia nervosa. (in Polish) Endokrynol Pediatr 9: 31-41, 2010c.

ZIORA K, OSWIECIMSKA JM, SWIETOCHOWSKA E, OSTROWSKA Z, STOJEWSKA M, GORCZYCA P, ROJEWSKA K, ZIORA-JAKUTOWICZ K, SZCZEPANSKA M, ZIORA D: Assessment of serum levels resistin in girls with anorexia nervosa. Part I. Relationship between resistin and body mass index. Neuro Endocrinol Lett 32: 691-696, 2011.

ZIORA K, OŚWIĘCIMSKA J, ŚWIĘTOCHOWSKA E, ZIORA D, STOJEWSKA M, SUWAŁA A, OSTROWSKA Z, GORCZYCA P, KLIMACKA-NAWROT E, LUKAS W, BŁOŃSKA-FAJFROWSKA B: Assessment of serum visfatin levels in girls with anorexia nervosa. Clin Endocrinol (Oxf) 76: 514-519, 2012. 